\title{
Social Integrity and the Cost of Equity Capital
}

\author{
Meng Wang \\ School of Management, Jinan University, Guangzhou, China \\ Email: jinanu@163.com
}

How to cite this paper: Wang, M. (2019) Social Integrity and the Cost of Equity Capital. Open Journal of Business and Management, 7, 229-244.

https://doi.org/10.4236/ojbm.2019.71016

Received: December 21, 2018

Accepted: January 13, 2019

Published: January 16, 2019

Copyright (c) 2019 by author(s) and Scientific Research Publishing Inc. This work is licensed under the Creative Commons Attribution International License (CC BY 4.0).

http://creativecommons.org/licenses/by/4.0/

Open Access

\begin{abstract}
After the establishment of the new China and the course of the Cultural Revolution, under the general trend of reform and opening up, China's market economy has developed rapidly, and the company's credit has become more and more important. Since ancient times, honesty has always been the basic morality of human beings, and integrity has always been respected by literati. Integrity is the spiritual leader of a person, the soul of a company, and integrity is also the connotation of a country. And social integrity has high requirements for the integrity of individuals and companies and even the country because it is related to the interests of everyone. Social integrity is the cornerstone of the market economy's continuous development in a good direction. It is also the foundation of the company's sustainable management and development. A good social integrity environment can bring hope to individuals, bring opportunities to enterprises, and bring endless power to the country. Based on the importance of social integrity to the market economy, this paper explores the impact of social integrity on the company's business development by searching and reviewing the literature on social integrity and the cost of equity capital. By analyzing the impact of social integrity on the company's business development, this paper puts forward a viewpoint: In other words, the cost of equity capital is affected by social integrity and is negatively correlated. And by designing an empirical solution, the data are compiled to prove this point.
\end{abstract}

\section{Keywords}

Social Integrity, Equity Capital Cost, Company Value

\section{Introduction}

Since the reform and opening up proposed by Deng Xiaoping, along with the rapid development of China's market economy, China's capitalist market has undergone a process from initial exploration to gradual improvement. As the 
market economy becomes more important, people are paying more and more attention to the integrity of the company. Integrity has always been the traditional virtue that people have promoted for thousands of years because it is not only the basic moral character of a person, but also the basic requirements of a country, and the basic idea that the world should have. Every subject in society should pay attention to the role of social integrity in the development of business and the role of the state in strengthening the country's economic strength, because it is not only the foundation of modern society, but also the pillar of the market economy. The phenomenon of dishonesty in the management of the company exists in the territory of each country of the earth, and integrity is the demand for stable and sustainable development of the mature market economy. In the history of American corporate development, the second largest bankruptcy case was the Enron incident, which occurred in 2001. Enron has been a leader in global companies, authoritative in the global goods, services and energy industries, and it ranks in the top 10 in Fortune magazine's US 500. However, in early December 2001, the company's bankruptcy announcement was suddenly released and it was protected by the New York Bankruptcy Court. The Enron incident also involved Andersen. Andersen's business cheating in the Enron incident seriously undermined the economic market order and caused serious illegal activities, which forced him to withdraw from the audit business. In the history of American accounting, Andersen was the first large firm to be investigated by criminals. The Enron incident seriously damaged the vitality of the recovery of the US economy and even the global economy. The embarrassing situation has hit the confidence of the global public. The US government and the US Congress have also attached great importance to the Enron incident. There are countless examples of such accounting fraud and corporate credibility. The major accounting frauds in the United States in 2002 were mainly Xerox's financial fraud incident, the second largest long-distance telephone company in the United States, the world's communications company's financial fraud, and Leidade's third place in the pharmaceutical chain. In 2003, Parmalat, the authoritative enterprise of Italian dairy products, was also deeply immersed in the abyss of accounting fraud; in 2005, insurance giant AIG was suspected of financial fraud; in 2007, Japan appeared in the Japanese version of the "Enron Incident", namely Japan's Sanyo Electric Company accounting fraud; In 2011, Japan's Olympus financial fraud case, SEC sued India's Satyam and Pricewaterhouse Coopers for $\$ 1$ billion in financial fraud; in 2014, UK TESCO fell into the biggest crisis in history due to financial fraud; Japan's Toshiba has also been reported to use financial fraud to make financial fraud, and its forgery profits have increased by nearly 150 billion yen.

The occurrence of the above incidents has seriously hurt the economies of various countries, and the public's confidence in the company has gradually weakened. The lack of social integrity exists not only in developed countries but also in developing countries and even weak countries. China's accounting fraud, financial fraud, and companies do not talk about integrity, there have been sen- 
sational melamine-tainted milk powder, Sudan red eggs, frequent use of ripening agents or preservatives of various fruits and vegetables, as well as a famous brand of milk was detected Events such as strong carcinogens have seriously harmed the health and interests of citizens, and their credibility has weakened. Recently, the outbreak of financial fraud cases such as Wanfushengke, Nanfang, Hailianxun, Greenland, Ziguang Guhan, Zhangzidao, Zhongkeyunwang (formerly Xiang Eqing) has made the public chilly, which has become commonplace. Due to various excuses for each other's defaults, random breaks between enterprises and false transactions between enterprises, the social groups do not talk about each other's credit, and the relationship between various groups of society is in thin ice. Transaction costs between enterprises and even groups of society have increased, and transaction efficiency has declined. This phenomenon has seriously hindered the healthy and stable development of the market economy. Therefore, this paper explores the relationship between social integrity and the cost of equity capital in business operations by collecting and collating literatures related to social integrity and equity capital costs, and examines the relationship between social integrity and equity capital costs through designing empirical solutions.

The follow-up content of this paper: The second part mainly expounds the literature research on social integrity and the cost of equity capital, and discusses the relationship between social integrity and equity capital. The third part mainly deals with the theoretical analysis of the relationship between social integrity and the cost of equity capital. It discusses how social integrity affects the cost of equity capital. The fourth part mainly uses empirical evidence to prove the impact of social integrity on the cost of equity capital, design empirical evidence and empirical results analysis, and then discuss relevant theoretical analysis and research hypotheses.

\section{Literature Review}

\subsection{The Literature Review of Social Integrity}

With the rapid development of the social economy, the various dishonest phenomena in the society have caused great harm to individuals, enterprises and the country, and we have become more aware of the importance of social integrity to the market economy and national stability. The literature on scholars' research on social integrity is fruitful.

From the perspective of social development, Jiang Zhengdong (2002) proposed that social integrity is the most basic moral character and social relationship, which is widely existed in every field of social life. It is divided into three types of integrity: one is political integrity, and the other is economic integrity. The third is political integrity and ideological and cultural integrity. Long Jingyun (2002) puts forward the necessary conditions for the integrity of the market economy to operate healthily [1]. Yue Shangzhi (2005) published an article proposing that the most fundamental of the market economy is the credit 
economy and the contracting economy [2]. The foundation of the growth and maturity of the contemporary market economy cannot be separated from honesty. If there is no rule and no rule, if the market economy wants to be stable, healthy and sustainable, then it must be honest. Only on the basis of good faith can the economic order be maintained. Wang Langling (2005) proposed that social integrity is divided into three types of integrity: one is personal integrity, the other is corporate integrity, and the third is government integrity [3]. At the same time, Ma Chao et al. (2010) supplemented Wang Langling's (2005) social integrity perspective [4].

From the perspective of market economy, Hu Bifang (2003) believes that the necessary condition for a market economy is, to be honest, and trustworthy [5]. The real market economy should be the legal economy, and it should be a credit economy. In the day-to-day management of enterprises, credit transactions can greatly reduce the cost of the company's various transactions, and enlarge the scope of development of the company. The transaction can be carried out, and the premise that the economy can operate is that the universal honesty and trustworthiness can be effectively implemented. The necessary condition for each enterprise to survive in society is to always be honest and trustworthy. The enterprise survives in the market economy, and it is equivalent to the credit economy. If the enterprise loses its sense of social responsibility, the society will lose trust in the enterprise. If the company does not abide by the credit and does not comply with the market order, it will eventually lose the entire market. Xia Weidong (2003) believes that integrity is included in the most fundamental ethics of the market economy [6]. Xu Yanming, Shi Lin (2014) shows that as far as the company is concerned, there is a high risk behind integrity [7]. In a collaborative relationship, if a company does not speak honestly and adheres to its own credit, it will certainly pay the corresponding cost - the cost of integrity. If there is cost, there will be benefits. In terms of the cost of good faith, enterprises will also receive corresponding benefits while paying the cost of integrity. Integrity will inevitably pay the so-called integrity costs. In the course of the company's business dealings, if the customer is not honest, but fulfills its fiduciary duty, it will certainly bring losses to the company. Therefore, in the management and development of the company, most of them will be tempted to pay the costs formed by honesty, so as to avoid the company itself suffering losses. Zhao Xu (2011) used empirical research to prove that the company's operating performance and integrity level are in the same relationship [8]. Yang Xiongsheng (2002) believes that accounting integrity is necessary for the development of the market economy; accounting integrity is closely related to the "three public" principle of the market economy [9]. Xiao Zuoping and Zhou Jiajia (2012) published an empirical study to prove the relationship between the legal system environment and the cost of equity capital [10]. Xie Fenghua and Bao Gongmin (2005) published an empirical study to prove that the credit level significantly positively affects the competitive advantage of enterprises [11]. 


\subsection{The Literature Review of the Cost of Equity Capital}

The cost of capital is the opportunity cost of investment capital, which is the expected remuneration that the investor proposes to obtain, and is numerically weighted by the cost of various capital elements. The cost of equity capital refers to the price paid by an enterprise to obtain funds through the issuance of ordinary stock. It is equal to the dividend yield and the return on capital gain, which is the necessary rate of return for shareholders. Investors' income comes from capital gains and dividends. The distribution of dividends depends on the company's financial operations. The stock price is also changing rapidly. Therefore, there are two commonly used methods for measuring the cost of equity capital, one is the internal rate of return method, and the other is the risk compensation method. Risk compensation methods appear in early research. There are three typical measurement methods: one is the arbitrage pricing theory, the other is the capital asset pricing model, and the third is Fama \& French three-factor model.

Foreign studies on the cost of equity capital include: The capital asset pricing model proposed by Sharpe (1964) is based on asset portfolio theory [12]. Lintner (1965) and Black (1972) complement the concept of capital asset pricing models. Ross (1976) clarified the arbitrage pricing theory, which promoted the capital asset pricing model. Arbitrage pricing theory believes that an important factor in the market equilibrium price is arbitrage behavior. If the market cannot achieve equilibrium, there will be a speculative opportunity in the market, that is, risk-free arbitrage [13]. French and Fama (1993) have established a well-known three-factor model (the FF3 model) [14]. The empirical research data of the FF3 model clarifies that there are book market value and scale effect ratio effects in the market, which are based on the following two aspects: one is the smaller scale of company development, and the other is the higher book value ratio. Both of these factors mean that the company has a higher risk, and investors will make corresponding income based on the risk. The calculation of these models is based on historical time, and the use of equity capital costs is based on the future. Unless the following three aspects: First, the company's revenue cyclical, second, financial leverage, and third, there is no significant change in operating leverage, otherwise the reliability of the calculation is weak. As a result, experts and scholars have tended to use stock prices and analyst forecasts, as many studies have found that using old-time data makes it difficult to make scientific predictions about the company's future rate of return. Williams (1938) first elaborated that the most fundamental stock intrinsic value evaluation model is a dividend discount model, which feels that the value of stocks is the sum of the present values of dividends for each year [15]. Edwards and Bell (1961) based on the premise of the dividend discount model, they elaborated the residual income valuation model [16]. The residual income is the balance of the company's net profit minus the minimum remuneration proposed by the investor. However, Swaminathan and Gebhardt, Lee (2001) argue that on the premise of a clean 
surplus assumption, the value of the stock is reflected in the discounted and book value of the infinite residual income [17]. Their empirical results show that the old projection model is inferior to the GLS model in the budget of equity capital cost. Therefore, for the measurement of the cost of equity capital, the GLS model is relatively widely used in China in recent years.

As far as the cost of equity capital is concerned, domestic scholars mostly start from the perspective of corporate governance. Kong Weicheng and Xue Hong (2005) found that the shareholding ratio of the largest shareholder is significantly related to the cost of equity capital [18]. Shen Hongtao and Yang Lan (2008) have shown that the quality and quantity of information disclosure has a significant anomalous correlation with the cost of equity capital. Yan Huahong (2011) analyzed the data of all listed companies in China from 2004 to 2008 and found that the independence of the board of directors was negatively correlated with the cost of equity financing, but it was not obvious [19]. Wang Yumei and Gong Yanchen (2015) found that the transparency of information disclosure and the cost of equity capital of listed companies are an anomalous relationship [20].

In summary, scholars' research on the cost of equity capital is mostly based on the perspective of corporate governance and measurement models. Few people analyze the cost of equity capital from the standpoint of social integrity. This article is based on social integrity to explore its impact on the company's equity capital costs.

\section{Theoretical Analysis and Research Hypothesis}

Since the 21st century, various kinds of lack of credibility in society have seriously disrupted social stability and market order. The failure of the company to act with integrity has not only led to a significant reduction in the efficiency of economic operations, the power of moral restraint has been weakened, the social benefits have been destroyed, and the healthy and stable development of the country's market economy and the image of the country have been seriously damaged. It also weakens credibility, erodes people's spiritual world, and distorts interpersonal relationships. Under the current situation, how important social problems we urgently need to face and solve are how to effectively cope with the increasingly serious social credibility crisis. From a national perspective, the state proposes to create social integrity and strengthen corporate integrity. On March 5, 2005, Wen Jiabao, as the Prime Minister of the State, mentioned the issue of integrity in his government work report. He believed that the establishment of a socialist harmonious society is inseparable from the construction of integrity. In October 2011, Wen Jiabao once again stressed the importance of strengthening the building of social integrity. Leaders of other countries also maintained their approval attitude and proposed to "put the integrity construction in a prominent position." On June 29, 2007, the "Labor Contract Law" promulgated by the state clearly defined the statutory responsibility for breach of the labor contract, which effectively addressed and circumvented the crisis of credibility in the field of labor and employment in China. In October 2009, the 
State Council issued the first draft of the "Regulations on the Management of Credit Information," which widely listened to and collected social opinions. In July 2011, the State Council once again issued the draft of the Regulations to solicit and listen to the opinions of the society more widely; Near the end of 2012, the "Regulations on the Management of Credit Information" was passed by the State Council. Since 2002, under the background of a market economy and national policy, scholars have conducted an extensive and in-depth analysis of social integrity issues. The cost to the untrustworthy behavior of the enterprise subject is too small, that is, the low cost of the breach of trust is an important reason why the phenomenon of dishonesty is so common.

From a management point of view, Xia Weidong (2003) proposed that there is no credit system, there is no "virtual currency", and there is no market order [6]. $\mathrm{Wu}$ Shenyuan and Xu Jianhua (2001) believe that a good social credit environment will help increase the trust of both parties, making transaction costs significantly lower, and the transaction process will be much smoother [21]. Xiao Zuoping and Zhou Jiajia (2012) have shown that the improvement of the legal system environment can play three main roles: one is to reduce the efficiency of the means of plunder, the other is to increase the cost of plunder, and the third is to plunder the risk [10]. Therefore, the improvement of the legal system environment can reduce the cost of equity capital of the company. Meng Xiaojun, Xiao Zuoping (2010) published an article pointing out that voluntary social responsibility information disclosure can improve the level of information disclosure, reduce the losses caused by information asymmetry, deepen the understanding of both sides of the enterprise, and reduce the uncertainty of the company's future development prospects. In turn, the cost of capital is reduced. On the other hand, in the context of good social integrity, in order to better occupy the market, enterprises will gradually pay more and more attention to the improvement of their competitive advantage. If the company has a good competitive advantage, it can use this advantage to prove its strength, so that investors can see the good development prospects and future of the company, and thus have full confidence in the enterprise. Enterprises also have the ability to negotiate with investors, which can reduce the risk-return proposed by investors and ultimately reduce the cost of capital. With social integrity, even if a company has a dispute in the course of business dealings, it will be resolved through self-deliberation because of mutual trust. This will greatly reduce transaction costs, improve the operational efficiency of the economic market, and the welfare level of the entire society will also be greatly improved. A good social integrity environment will provide enterprises with a fairer and more just competitive environment. In order to better seize the business opportunities, enterprises will speed up investment and ensure even improve efficiency, so as to improve investment efficiency and ultimately To achieve the result of reducing the cost of the company's equity capital; a good social integrity environment is conducive to constraining the company's malicious competition behavior, the company faces high cost of looting, pays more attention to its own behavior, thus establishing a 
good corporate reputation, and investors also More willing to invest in the enterprise, and ultimately reduce the cost of equity capital of the enterprise; a good social integrity environment is conducive to the implementation of the law, increasing the risk of the company breaking the law, so that the social groups form a good supervision atmosphere, and then the enterprise The cost of equity capital has also been reduced. For investors, a good social integrity environment can reduce investment risks.

Based on the above analysis, I put forward a hypothesis: the improvement of social integrity will reduce the cost of corporate equity capital.

\section{Research Program Design}

\subsection{Measurement of the Cost of Equity Capital}

The measurement model of the cost of equity capital is endless. It is proposed by the GLS model proposed by Gebhardt et al. (Gebhardt et al., 2001) and the CT model proposed by Claus and Thomas (Claus and Thomas, 2001), Gordon and Gordon. The GGM model (Gordon and Gordon, 1997 [22]), ES model (Easton, 2004) and Ohlson and Juettner Nauroth proposed OJN model (Ohlson and Juettner Nauroth, 2005) Easton raised. In China, the better applicability of these models is the GLS model (Lu Zhengfei and Ye Kangtao, 2004). Therefore, this paper uses the GLS model to measure the cost of equity capital. The specific model is as follows (1).

$$
\mathrm{COE}=\beta_{0}+\beta_{1} \text { Honesty }+\sum(\lambda \text { Control_Variable })+\varepsilon
$$

Among them, $M_{t}$ is the year-end equity market value, $\mathrm{COE}$ is the equity capital cost, $B_{t}$ is the equity book value at the end of the year, and $E_{t}$ is the market forecast for the future at the end of $\mathrm{t} . \mathrm{ROE}_{t+k}$ is the return on net assets of $t+k$ years. When $1 \leq K \leq 3$, it is defined as the predicted surplus $E_{t+k}$ of $t+$ $k$ years, except for the equity book value $B_{t+k-1}$ of the previous year, when $4 \leq K$ $\leq 11$, At the time, define the median of the industry's return to the industry's median in the past decade (excluding the loss-making company sample). When $k \geq 12$, define the median of the industry for the past ten years. $B_{t+k}$ is the book value of equity based on "clean earnings accounting", $B_{t+k}=B_{t+k-1}+E_{t+k}-D_{t+k}$, where $D_{t+k}$ is the cash dividend of $t+k$ years, $D_{t+k}=r * E_{t+k}, r$ is the current dividend payout rate when the $t$ year surplus is positive $r$ equals the $t$ year cash dividend divided by the accounting surplus. When the $t$ year surplus is negative, $r$ is equal to the ratio of the $t$ year cash dividend to the 6\% total assets (Gebhardt et al., 2001), and the Winsorized tail-finalization of $r$, so that it is between $[0,1]$.

\subsection{Measurement of Social Integrity}

Wang Lu et al. (2013), "China Business Operating Environment Index by province in 2013 Report" (hereinafter referred to as the index "business environment index" is to measure the level of social integrity (Honesty) defined as follows editor: Social Cheng confidence level (Honesty) is defined as the Honest Social 
Environmental Index in the Business Environment Index. The higher the index, the higher the level of social integrity. In the current study, the 2013 Business Environment Index was highly recognized and adopted by most research scholars. In addition, considering the small change in social integrity level, this paper still uses the 2013 Business Environment Index as a source of data for the level of social integrity (Honesty).

\subsection{Model Construction and Variable Definition}

To empirically test the effect of social integrity on the cost of equity capital (ie, hypothesis), we constructed the following test model:

$$
\mathrm{COE}=\beta_{0}+\beta_{1} \text { Honesty }+\sum(\lambda \text { Control_Variable })+\varepsilon
$$

$\mathrm{COE}$ is the cost of equity capital, $\beta_{0}-\beta_{2}$ and $\lambda$ are the coefficient of the corresponding test model, Honesty is the social dummy of corporate virtual variables, Control_Variable is the control variable (the control variables of the two models are the same), and e is the random error term. The variables are defined in Table 1 below.

Table 1. Variable definitions.

\begin{tabular}{|c|c|c|}
\hline Variable name & Variable symbol & Variable definitions \\
\hline \multicolumn{3}{|l|}{ Dependent variable } \\
\hline Cost of equity capital & $\mathrm{COE}$ & Implied equity capital cost based on the GLS model (1) \\
\hline \multicolumn{3}{|l|}{ Explanatory variables } \\
\hline Social integrity level & Honesty & $\begin{array}{l}\text { Honest Social Environment Index in Business } \\
\text { Environment Index }\end{array}$ \\
\hline \multicolumn{3}{|l|}{ Control variable } \\
\hline Beta coefficient & Beta & Stock beta \\
\hline Company Size & Lnassets & Natural logarithm of total assets at the end of the year \\
\hline Book market value ratio & $\mathrm{Bm}$ & $\begin{array}{l}\text { The ratio of book value of shareholders' equity to } \\
\text { market value }\end{array}$ \\
\hline Business risk & Oprisk & $\begin{array}{l}\text { The ratio of the sum of non-current assets at the end of } \\
\text { the year to the total assets at the end of the year }\end{array}$ \\
\hline Financial Risk & Finrisk & $\begin{array}{l}\text { The ratio of total liabilities at the end of the year to total } \\
\text { assets at the end of the year }\end{array}$ \\
\hline Hand turnover rate & Turnover & $\begin{array}{l}\text { The ratio of annual number of shares traded to a total } \\
\text { number of shares outstanding at the end of the year }\end{array}$ \\
\hline Profitability & Roa & $\begin{array}{l}\text { The ratio of annual net profit to total assets at the end of } \\
\text { the year }\end{array}$ \\
\hline Asset turnover & Assturn & $\begin{array}{l}\text { The ratio of annual operating income to total assets at the } \\
\text { end of the year }\end{array}$ \\
\hline Growth & Income grow & The annual operating income growth rate \\
\hline Dividend payout ratio & Rdiv & The ratio of total annual cash dividends to the net profit \\
\hline Equity concentration & Hfd & $\begin{array}{l}\text { The sum of the squares of the shareholding ratios of the } \\
\text { first to fifth largest shareholders at the end of the year }\end{array}$ \\
\hline Year & Year & Set dummy variables for each year from 2005 to 2013 \\
\hline
\end{tabular}




\subsection{Sample Selection and Data Source}

In December 2003, the China Securities Regulatory Commission explicitly required listed companies to disclose actual controller information. This article considers all listed companies in Shanghai and Shenzhen as the research object. Therefore, we use the listed companies in 2004-2013 as the primary sample. On this basis, we will eliminate the following company samples: 1) the company is in ST or PT; 2) The company is not a company that only issues A shares; 3) companies belonging to small and medium-sized companies or GEM; 4) companies with asset-liability ratio greater than 1 ; 5) financial and insurance companies; 6) samples with missing data; 7) Companies with less than $10 \%$ ultimate control (LA Porta et al., 1999) believe that effective control cannot be less than 10\%). The data is all from the CSMAR database. The CSMAR database is an economic and financial research database with large scale, accurate information and comprehensive data in China. It is developed by Guotaian Company from the academic research needs and draws on the professional standards of the internationally renowned databases such as CRSP and Standard \& Poor's Compustat. It is characterized by accuracy, authority, comprehensiveness, timeliness, and bilingualism. The CSMAR database series is the only database product in Greater China to be selected as the Wharton Research Service System (WRDS) in the United States. It has been highly recognized by Nobel laureate Robert William Fogel. Finally, we get 8696 observations.

\section{Empirical Results and Analysis}

\subsection{Descriptive Statistics}

Table 2 shows descriptive statistics for all variables. From the data in Table 2, it can be clearly found that the average and median cost of equity capital (COE) are 0.087 and 0.082 , respectively, and the value of the standard deviation is 0.046 . The minimum value is approximately equal to 0 , and the maximum value is 0.855 . It shows that the sample company's equity capital cost has a big difference, and the volatility is large. The mean and median values of the dummy variable Honesty are 3.105 and 3.120 respectively, the standard deviation is 0.18 , the minimum is 2.58 , and the maximum is 3.56 , which indicates that the sample company's social integrity level has greater volatility.

\subsection{Univariate Analysis}

The groups in the table are divided into low-level and high-level groups according to the annual median of social integrity, that is, if the social integrity of observation is lower than the median of the social integrity of the year, it is a low-level group. Otherwise, it belongs to the high-level group, then the mean $\mathrm{T}$-test, and finally the Wilcoxon median $\mathrm{Z}$ value is tested.

In the full sample matching group of Table 3 , the mean and median cost of 
equity capital of the sample group with low social integrity level were $8.97 \%$ and $8.26 \%$, respectively. For the sample group with high social integrity level, the Table 2. Descriptive statistics.

\begin{tabular}{|c|c|c|c|c|c|c|c|c|}
\hline variable & $\begin{array}{l}\text { Number of } \\
\text { observations }\end{array}$ & Average & $\begin{array}{l}\text { Standard } \\
\text { deviation }\end{array}$ & $\begin{array}{l}\text { Minimum } \\
\text { value }\end{array}$ & $25 \%$ & median & $75 \%$ & Maximum \\
\hline Coe & 8783 & 0.087 & 0.046 & 0.000 & 0.056 & 0.082 & 0.112 & 0.855 \\
\hline Honesty & 8821 & 3.105 & 0.180 & 2.580 & 2.970 & 3.120 & 3.240 & 3.560 \\
\hline Beta & 8780 & 1.114 & 0.243 & -0.342 & 0.984 & 1.132 & 1.260 & 2.355 \\
\hline lnassets & 8821 & 21.876 & 1.172 & 15.577 & 21.058 & 21.785 & 22.579 & 27.387 \\
\hline $\mathrm{Bm}$ & 8821 & 0.485 & 0.317 & 0.002 & 0.247 & 0.415 & 0.651 & 4.413 \\
\hline Oprisk & 8817 & 0.471 & 0.222 & 0.000 & 0.304 & 0.466 & 0.640 & 0.989 \\
\hline Finrisk & 8821 & 0.514 & 0.188 & 0.007 & 0.382 & 0.530 & 0.655 & 0.994 \\
\hline Turnover & 8821 & 5.420 & 3.676 & 0.007 & 2.671 & 4.504 & 7.203 & 31.030 \\
\hline Roa & 8820 & 0.033 & 0.073 & -2.746 & 0.011 & 0.030 & 0.057 & 2.163 \\
\hline Assturn & 8820 & 0.726 & 0.586 & 0.001 & 0.356 & 0.593 & 0.911 & 8.097 \\
\hline Income grow & 8739 & 0.212 & 0.540 & -0.650 & -0.015 & 0.125 & 0.292 & 3.767 \\
\hline Rdiv & 8821 & 0.207 & 0.287 & 0.000 & 0.000 & 0.101 & 0.321 & 1.589 \\
\hline Hfd & 8821 & 0.180 & 0.130 & 0.006 & 0.076 & 0.147 & 0.256 & 0.800 \\
\hline
\end{tabular}

Table 3. Univariate analysis.

\begin{tabular}{|c|c|c|c|c|c|c|c|}
\hline $\begin{array}{l}\text { Institutional } \\
\text { environment }\end{array}$ & $\begin{array}{l}\text { Number of } \\
\text { observations }\end{array}$ & Mean & median & $\begin{array}{c}\text { Mean } \\
\text { difference }\end{array}$ & T-value & $\begin{array}{c}\text { Median } \\
\text { difference }\end{array}$ & $\mathrm{Z}$ value \\
\hline $\begin{array}{l}\text { Low-level of } \\
\text { social integrity }\end{array}$ & 4392 & $8.97 \%$ & $8.26 \%$ & & & & \\
\hline $\begin{array}{l}\text { High-level of } \\
\text { social integrity }\end{array}$ & 4391 & $8.50 \%$ & $8.23 \%$ & $0.47 \%$ & $4.728^{* * *}$ & $0.03 \%$ & $2.255^{* *}$ \\
\hline
\end{tabular}

Note: ${ }^{*}{ }^{* *}$, and ${ }^{* * *}$ indicate that the regression coefficient is tested by the significance level of $10 \%, 5 \%$, and $1 \%$, respectively.

mean and median cost of equity capital were $8.50 \%$ and $8.23 \%$, respectively. The difference between the average value of the equity capital cost of the two groups of high and low social integrity is $0.47 \%$, which is significant at the level of $1 \%$. The difference between the median level of equity capital cost of the high and low levels of social integrity is $0.03 \%$, which is significant at the $5 \%$ level. This shows that the improvement of social integrity will reduce the cost of corporate equity capital and verify the hypothesis.

\subsection{Multiple Regression}

Table 4 shows the results of multiple regressions of social integrity and equity capital costs. The second column is the full sample regression, the third column is the national enterprise subsample, and the fourth column is the non-state enterprise subsample. The full sample of observation data used in this paper con- 
sists of a sample of state-owned enterprises and a sample of non-state-owned enterprises. The Hausman test and the Sargan-Hansen over-identification test Table 4. Social integrity level regression results.

\begin{tabular}{|c|c|c|c|}
\hline variable & Full sample & $\begin{array}{c}\text { The sample of } \\
\text { state-owned enterprises }\end{array}$ & $\begin{array}{c}\text { Non-state enterprise } \\
\text { sample }\end{array}$ \\
\hline \multirow[t]{2}{*}{ Honesty } & $-0.017^{\star \star *}$ & -0.007 & $-0.023^{\star *}$ \\
\hline & $(-3.121)$ & $(-1.079)$ & $(-2.157)$ \\
\hline \multirow[t]{2}{*}{ Beta } & 0.002 & 0.001 & 0.006 \\
\hline & $(0.826)$ & $(0.625)$ & (1.436) \\
\hline \multirow[t]{2}{*}{ Lnassets } & $0.002^{*}$ & 0.001 & 0.003 \\
\hline & (1.908) & $(0.478)$ & $(1.322)$ \\
\hline \multirow[t]{2}{*}{$\mathrm{Bm}$} & $0.047^{* * *}$ & $0.048^{* * *}$ & $0.048^{* * *}$ \\
\hline & $(21.607)$ & (19.190) & $(10.700)$ \\
\hline \multirow[t]{2}{*}{ Oprisk } & 0.005 & 0.005 & 0.008 \\
\hline & (1.117) & $(0.926)$ & $(0.996)$ \\
\hline \multirow[t]{2}{*}{ Finrisk } & $0.071^{* * *}$ & $0.067^{\star * *}$ & $0.073^{* * *}$ \\
\hline & $(16.151)$ & (12.330) & $(8.908)$ \\
\hline \multirow[t]{2}{*}{ Turnover } & $-0.000^{* * *}$ & -0.000 & $-0.001^{\star * *}$ \\
\hline & $(-2.872)$ & $(-0.877)$ & $(-3.670)$ \\
\hline \multirow[t]{2}{*}{ Roa } & $-0.093^{\star * *}$ & $-0.088^{\star * \star}$ & $-0.072^{\star \star \star}$ \\
\hline & $(-14.306)$ & $(-10.121)$ & $(-6.726)$ \\
\hline \multirow[t]{2}{*}{ Assturn } & -0.001 & 0.002 & $-0.006^{\star}$ \\
\hline & $(-0.849)$ & $(0.898)$ & $(-1.861)$ \\
\hline \multirow[t]{2}{*}{ Income grow } & $-0.003^{\star * *}$ & -0.001 & $-0.004^{\star * *}$ \\
\hline & $(-4.490)$ & $(-1.270)$ & $(-3.457)$ \\
\hline \multirow[t]{2}{*}{ Rdiv } & $0.004^{* * *}$ & $0.004^{\star *}$ & $0.006^{\star}$ \\
\hline & $(2.760)$ & (2.073) & $(1.736)$ \\
\hline \multirow[t]{2}{*}{$\mathrm{Hfd}$} & $-0.028^{\star \star \star}$ & $-0.025^{\star * *}$ & $-0.052^{\star \star \star}$ \\
\hline & $(-3.846)$ & $(-2.859)$ & $(-3.467)$ \\
\hline \multirow[t]{2}{*}{ Constant } & 0.019 & 0.024 & -0.009 \\
\hline & $(0.631)$ & $(0.623)$ & $(-0.147)$ \\
\hline Year & control & control & control \\
\hline Industry & control & control & control \\
\hline Observations & 8696 & 5781 & 2787 \\
\hline Adjusted R 2 & 0.313 & 0.356 & 0.213 \\
\hline F statistic & 130.7 & 102.1 & 32.30 \\
\hline
\end{tabular}

Note: ${ }^{*}{ }^{* *}$, and ${ }^{* * *}$ indicate that the regression coefficient is tested by the significance level of $10 \%, 5 \%$, and $1 \%$, respectively. The numbers in parentheses in the table are the $\mathrm{T}$ values of the two-tailed $\mathrm{T}$-test of the regression coefficients; the variance expansion factors (VIF) of all explanatory variables and control variables are significantly lower than 10 . 
found that the random effects model is not applicable to the full-sample model and the SOE sample model. Therefore, in the full sample model and the SOE sample model, we used the individual fixed effect model for regression testing. The $\mathrm{F}$ values of the full sample and the state-owned enterprise samples were all significant at the level of $1 \%$, indicating that the two model coefficients were overall significant.

In the full sample model, the coefficient of social integrity is -0.017 ( $\mathrm{T}$ value $=$ -3.11 ), which is clearly negative at the $1 \%$ level. In the sample of non-state enterprises, the coefficient of social integrity is -0.023 ( $\mathrm{T}$ value $=-2.157$ ), which is significantly negative at the level of $5 \%$. The results of the full sample group and the non-state-owned enterprise sample group proved that the greater the social integrity, the smaller the cost of equity capital, and the hypothesis was verified. In the sample model of state-owned enterprises, the social credit coefficient is -0.007 , and the result is not significant. This shows that social integrity does not have a big impact on the cost of corporate equity capital for state-owned enterprises. For non-state-owned enterprises, social integrity plays a role in the cost of corporate equity capital. The reason for this phenomenon is that I believe that because the state-owned enterprises are funded by the government, they will not consider divesting or not investing because of the social integrity of the enterprise. When state-owned enterprises face serious credibility crisis, more treatment is Improve and reform the company's management system or delegate new leaders to control the company.

\section{Conclusions and Policy Recommendations}

Based on the development of Chinese companies, this paper analyzes the impact of social integrity on the cost of equity capital of enterprises. Then, based on the research samples of all listed companies from 2004 to 2013, the empirical scheme is designed. The research hypothesis of theoretical deduction is based on the individual fixed effect model. An empirical test was conducted. Through research, it is found that: 1) For state-owned enterprises, social integrity has not had much impact on the cost of equity capital. This shows that state-owned enterprises have government restraint, which leads to greater social responsibility and political costs. The government will not divest the company because of its lack of social integrity. When there is a lack of integrity in state-owned enterprises, they often adopt measures to improve management and management or delegate others to take over enterprises. From another perspective, because of the government's preferential treatment for state-owned enterprises and invisible risk guarantees, social integrity is the cost of their equity capital. The effect is small. 2) In the non-state-owned enterprises and the full sample group, social integrity is significantly negatively correlated with the cost of equity capital of the enterprise, which indicates that the higher the social integrity, the less the cost of equity capital required by the enterprise.

It can be found that the role of social integrity in the cost of equity capital 
cannot be underestimated. Therefore, continuous improvement of social integrity is an indispensable measure. Only by establishing complete integrity can the problem be solved fundamentally. The establishment of a good faith system is a long-term, complex, and gradual process. Therefore, this paper believes that we can jointly promote the establishment of a social credit system from the following aspects:

1) Improving the information disclosure and disclosure system of enterprises, especially listed companies. The disclosure and disclosure of enterprise information are conducive to the establishment of a good securities market and investment market order. There are information distortions and incomplete information in the information disclosure and disclosure of Chinese enterprises, especially listed companies, and it is urgent to improve relevant institutional arrangements. In addition, the establishment of China's government information disclosure and disclosure system has been effective in China, but there are still problems such as low information disclosure and formality. Therefore, it makes relevant provisions on the authenticity and timeliness of information, broadens the channels for information disclosure and disclosure, publicizes information from multiple angles, aspects, and means, and closely links information disclosure and disclosure with punishment to ensure the viability of the system.

2) Increasing the punishment for untrustworthy behavior and increase the opportunity cost of untrustworthy people. And, it needs to cover three aspects: individual, business and government. In the aspect of personal integrity, we will focus on the integrity considerations of personal assets, credit, and interpersonal relationships into the personal credit system, increase penalties for untrustworthy behavior, and form a perfect personal integrity supervision mechanism; in order to ensure economic order stability in the enterprise integrity level, it is necessary to raise the cost of default of enterprises, and incorporate product supervision and inspection, enterprise credit, corporate financial supervision, and labor contracts of employees on employees into the punishment mechanism to improve the opportunity cost and legal constraints brought about by corporate turnover. On the level of government integrity, we should increase the supervision and investigation of civil servants themselves, increase punishment for corruption, strengthen the standardization of power boundaries, and ensure that there are laws to follow, laws to follow, law enforcement to be strict, and violations of law.

3) Strengthening social integrity education. Vigorously promoting the propaganda work of the mainstream media on social integrity and strengthen the integrity education of young people. At the same time, it is necessary to advocate enterprises to establish a culture of integrity and enhance the awareness of honesty and integrity of civil servants.

4) Improving intermediary organizations such as industry associations to form self-monitoring and restraint among enterprises. Standardizing government behavior and giving full play to the government's macro guidance role can also better promote the establishment of a social credit system. 


\section{Conflicts of Interest}

The authors declare no conflicts of interest regarding the publication of this paper.

\section{References}

[1] Long, J.Y. (2002) Integrity: The Moral Soul of the Healthy Development of the Market Economy. Philosophical Research, 8, 27-34.

[2] Yue, S.Z. (2005) Thoughts on the Construction of Accounting Integrity Evaluation System. Accounting Research, 4, 73-76.

[3] Wang, L.L. (2005) Social Integrity Is the Basis for Sustainable Economic Development. Academic Exchange, 7, 60-63.

[4] Ma, C., Shen, T. and Yan, H.P. (2010) The Roots of China's Social Integrity Loss and Its Countermeasures. Development Research, 2, 138-141.

[5] Hu, B.F. (2003) On the Reconstruction of Social Integrity. Enterprise Economy, 8, $14-15$.

[6] Xia, W.D. (2003) On the Relationship between Honesty and Market Economy. Teaching and Research, 4, 8-14.

[7] Xu, Y.M. and Shi, L. (2014) Analysis of Social Integrity Costs and Benefits. Modern Business, 12, 24-25.

[8] Zhao, X. (2011) Empirical Research on the Integrity and Enterprise Value of Listed Companies. Journal of Shanxi University of Finance and Economics, 1, 94-100.

[9] Yang, X.S. (2002) Rational Thinking on Accounting Integrity Problem. Accounting Research, 3, 6-12.

[10] Ping, X.Z. and Zhou, J.J. (2012) Institutional Environment and the Cost of Equity Capital-A Comparison between Chinese Provincial Data. Securities Market Herald, 8, 19-27.

[11] Xie, F.H. and Bao, G.M. (2005) Research on the Relationship between Corporate Integrity and Competitive Advantage-Based on the Empirical Investigation of 188 Enterprises in Suzhou and Other Places. Nankai Management Review, 4, 21-22.

[12] Sharpe, W.F. (1964) Capital Asset Prices: A Theory of Market Equilibrium under Conditions of Risk. The Journal of Finance, 19, 425-442.

[13] Ross, S.A. (1976) The Arbitrage Theory of Capital Asset Pricing. Journal of Economic Theory, 13, 341-360. https://doi.org/10.1016/0022-0531(76)90046-6

[14] Fama, E.F. and French, K.R. (1993) Common Risk Factors in the Returns on Stocks and Bonds. Journal of Financial Economics, 33, 3-56. https://doi.org/10.1016/0304-405X(93)90023-5

[15] Williams, B. (1938) The Theory of Investment Value. Harvard University Press, Cambridge, 238-240.

[16] Edwards, E. and Bell, P. (1961) The Theory and Measurement of Business Income. University of California Press, Berkeley, 176-179.

[17] Gebhardt, W.R., Lee, C. and Swaminathan, B. (2001) Toward an Implied Cost of Capital. Journal of Accounting Research, 39, 135-176. https://doi.org/10.1111/1475-679X.00007

[18] Kong, W.C. and Xue, H. (2005) Empirical Research on Corporate Governance, Investor Protection, and Equity Capital Costs. Business Economy, 5, 77-79.

[19] Yan, H.H. (2011) Research on the Relationship between Internal Governance and 
Capital Cost. Financial Research, 6, 54-58.

[20] Wang, Y.M. and Gong, Y.C. (2015) Research on the Relationship between Transparency of Information Disclosure and Cost of Equity Capital of Listed Companies. Journal of Xi an University of Arts and Science (Social Science Edition), 2, 86-89.

[21] Wu, S.Y. and Xu, J.H. (2001) Integrity: The Moral Basis of the Effective Operation of Modern Market Economy. Journal of Fudan University (Social Science Edition), 5, 1-6.

[22] Gordon, J.R. and Gordon, M.J. (1997) The Finite Horizon Expected Return Model. Financial Analysts Journal, 53, 52-61. https://doi.org/10.2469/faj.v53.n3.2084 